\title{
Introduction to the Proceedings of the 52nd European Marine Biology Symposium
}

The 52nd European Marine Biology Symposium (52nd EMBS) was held in Piran (Slovenia) for the first time under the organization of the Marine Biology Station Piran, National Institute of Biology. In 1969, the Marine Biology Station was established as an independent research group that later joined the Institute of Biology. The station is situated on the far northern Adriatic Sea, in a marine environment known for its high biodiversity, as illustrated in the cover image of this issue. The characteristics of the environment were also addressed in the sessions of the 52nd EMBS aiming to put forward novel and exciting topics in the field of marine biology. In total, 171 presentations, among them five keynote lectures, 74 oral and 92 poster presentations attracted attendees from 32 countries from Europe and further afield (Australia, Middle East, Asia), thus confirming once more Otto Kinne's legacy and the importance of the EMBS nowadays. Papers from the Symposium form the first part of this issue.

The 52nd EMBS started with a 'Marine Symbiosis' session, which stressed the importance of living together in different associations; it also uncovered a diversity of associations by using omics tools and novel experimental approaches. Moreover, U. Hentschel Humeida's keynote lecture highlighted the importance of sponge symbiosis to their survival and adaptation ability, as revealed by analysis of microbial metagenomes.

The 'Imaging in Marine Biology' session emphasized new achievements and approaches that are essential for adequate description and understanding of life processes in the marine environment. Adam P. Summers gave an exciting keynote lecture on biomimetic designs found in the marine environment and included possible solutions for a variety of technical challenges. In this issue, Chimienti et al. (2018) highlight the advantage of ROV over traditional fishing techniques in a visual census of the sea pen Pennatula rubra, a species with scarce distribution data from soft-bottom benthic communities.

The importance of physical-chemical and biological processes coupling two different environments, their intertwining, and support to ecosystem functions was the focus of the session 'Benthic-pelagic coupling'. M. Pfannkuchen explained in his keynote lecture the high variability in phytoplankton

Email: andreja.ramsak@nib.si species and their life strategies to compete for nutrient release. In this issue, Smodlaka Tanković et al. (2018) provides new evidence about zoea grazing on diatoms, including induced consequences on growth and abundance of Skeletonema marionoi, and also a decrease in the abundance of the toxic Pseudo-nitzschia calliantha.

Advances in sequencing technology fuelled the 'Marine metagenomics' session. High throughput sequencing enables rapid detection of climate change impacts, uncovers biodiversity, characterizes food webs, and is also the foundation of marine biotechnology for improvements in fishery and aquaculture. The latest findings on genomics of bivalve immunity and its immune response revealed how Mytilus galloprovincialis can survive in extreme conditions. In this regard, the discovery of genes coding for proteins involved in innate immunity was the focus of A. Pallavicini's keynote lecture.

The 'General' session covered a variety of topics, including A. Malej's overview on scyphozoan research in the Adriatic Sea from a historical perspective through modern scientific achievements, besides information of scyphozoans as pest and beneficial organisms for humans. Similarly, in the context that parasite and fungal infection can pose a serious threat to mussel aquaculture, Kovačić et al.'s paper in this issue (Kovačić et al., 2018) provides readers with new evidence about their prevalence in the Adriatic Sea. Many presentations were dedicated to anthropogenic influences, especially pollution, and their effects on the biodiversity of benthic communities. Changes in structure and function of nematode communities due to heavily contaminated sediments are described in Franzo et al.'s contribution (Franzo et al., 2018). Within the general session, there was a special topic dedicated to 'Mesophotic ecosystems'. This session focused on several aspects, including biodiversity, community functioning, and potential exploitation of marine-derived biomolecules from invertebrates inhabiting this peculiar environment.

We owe gratitude to our sponsors for their financial support. These are the companies Marjetica Koper, Mikro + Polo, VinaKoper, Chemass, CGS Labs and Zeiss; the Municipality of Koper, Municipality of Piran, LifeWatch Italy, Embassy of the United States of America, The Marine Biological Association of the United Kingdom (MBA); and the European Foundation of Marine Research Institutes and Stations (MARS). Finally, our deepest gratitude goes to all members of the Scientific and the Organizing Committees. 
Thank you for all the professional work and devotion during the organization of the 52nd EMBS.

\section{REFERENCES}

Chimienti G., Angeletti L., Rizzo L., Tursi A. and Mastrototaro F. (2018) ROV vs trawling approaches in the study of benthic communities: the case of Pennatula rubra (Cnidaria: Pennatulacea). Journal of the Marine Biological Association of the United Kingdom. doi:10.1017/Soo25315418000851.

Franzo A., Guilini K., Cibic T. and Del Negro P. (2018) Structure and function of nematode assemblages in contaminated sediments: what can we learn from the Mar Piccolo of Taranto (Ionian Sea)? Journal of the Marine Biological Association of the United Kingdom. doi:10.1017/Soo25315418000553.

Kovačić I., Pustijanac E., Ramšak A., Šebešćen D. and Lipić S. (2018) Variation of parasite and fungi infection between farmed and wild mussels (Mytilus galloprovincialis Lamarck, 1819) from the Adriatic Sea. Journal of the Marine Biological Association of the United Kingdom. doi:10.1017/Soo25315418000644. and

Tanković M.S., Baričević A., Perusco V.S., Melzer R.R., López A.I., Dömel J.S., Heß M., Kužat N., Pfannkuchen D.M. and Pfannkuchen M. (2018) Experimental evidence for shaping and bloom inducing effects of decapod larvae of Xantho poressa (Olivi, 1792) on marine phytoplankton. Journal of the Marine Biological Association of the United Kingdom. doi:10.1017/Soo25315418000449.

\section{Correspondence should be addressed to:}

A. Ramšak

Marine Biology Station Piran,

National Institute of Biology,

Fornače 41, 6330, Piran, Slovenia

email: andreja.ramsak@nib.si

Andreja Ramšak and Patricija Mozetič

Marine Biology Station Piran, National Institute of Biology,

Fornače 41, 6330 Piran, Slovenia 